\title{
SOCIO-ECONOMIC DETERMINANTS OF STUDENTS'ACADEMIC ACHIEVEMENT IN BUILDING TECHNOLOGY IN NORTH-CENTRAL NIGERIA
}

\author{
Yahaya Ibn Salihu and Mohd. Safarin Nordin \\ School of Education, Faculty of Social Science and Humanities, Universiti Teknologi, Johor Bahru, Malaysia \\ E-mail: yibnsalihu@mmail.com
}

\begin{abstract}
This study investigated socio-economic determinants of students' academic achievement in building technology in North-central Nigeria. It was a quest to probe into the incessant cases of students' poor achievement in building technology to identify students' determining factors. Survey research design was adopted in carrying out the study. Data were collected from 113 students on their socioeconomic attributes and their academic record. Data were analysed using descriptive and inferential statistics such as frequency, percentage, mean and multiple regression analysis. The results of the study showed that building technology education in Nigeria is male dominated and majority of colleges of education students in North-central Nigeria are under 20 years. Socio-economic determinants of students' academic achievement in building technology include gender, age, study hours, family size, stipends per month, group reading, students' health status, credit pass in SSCE and truancy. The challenges facing building technology students in the study area include epileptic power supply, inadequate ICTs, lack of functional building technology workshop among others.
\end{abstract}

Keywords: academic achievement, building technology, vocational and technical education

\section{INTRODUCTION}

Vocational and technical education has continued to receive global attention because of its strategic position in national economic growth and development. Okoye \& Arimonu [1] described technical and vocational education as a comprehensive term in the educational process involving, in addition to general education. The study of technologies and related sciences and acquisition of practical skills, attitudes, understanding and knowledge relating to occupations in various sectors of economic and social life. Vocational and technical education equips the recipients with practical and applied skills as well as basic scientific knowledge. According to Kehinde \& Adewuyi [2], vocational and technical education is fundamental to the development and industrialization of nations. This is because, the saleable skills and competencies that are required for economic growth and development of the nation are embedded in vocational and technical education. In affirmation, Manyindo [3] stated that vocational and technical education when properly developed provides the youths with knowledge, skills and training that satisfy the human resource demand of the nation.

National policy on education of Federal Republic of Nigeria [4] enumerated the objectives of vocational and technical education in Nigeria to include: (i) provision of trained manpower in applied science, technology and commerce particularly at subprofessional grades, (ii) provision of technical knowledge and vocational skills necessary for agricultural, industrial, commerce and 
economic development, (iii) provision of people who can apply specific knowledge to the improvement and solution of environmental problems for the use and convenience of man, (iv) giving an introduction of professional studies in engineering and other technologies, (v) giving training and impact the skill leading to the production of craftsmen, technicians and other skilled personnels who will be enterprising and self-reliant and (vi) enabling our young men and women to have intelligent understanding of the increasing complexity of technology. Aspects of vocational and technical education in Nigeria education system include: agriculture, home economics, business education, electrical and electronics technology, metal work technology, mechanical or automobile technology, woodwork technology and building technology. The focus of this study is on building technology.

Building technology according to Maurice et al. [5] is one of the vocational and technical education courses that focus on the application of engineering principles and technology to design and construction of buildings. As described by Okoro [6], building technology involves the technical methods, skills, processes, techniques, tools and raw materials needed for the construction and maintenance of buildings. Building technology borders on how technical and vocational education can be used to improve the quality of life of the individual and society by equipping learners with relevant scientific and technological skills, attitudes and values in building technology for livelihood. While justifying the significance of building technology, Egboh [7] noted that the major distinction between an advanced country and a developing one is to a large extent the difference between their levels of scientific and technological development in various areas of technology education, building technology inclusive. The objectives of building technology at college of education or ordinary national diploma levels in Nigeria as reported by UNESCO [8] include the provision of technicians that can assist the professional builder in the areas of production of simple buildings, maintenance of simple buildings, management of small projects, costing of simple construction works, cost control techniques in minor construction and engineering works and selection of materials and techniques for new building systems. Unfortunately, these objectives are far from been achieved with the current poor interest and achievement of students in building technology most especially at colleges of education level.

Kolawole \& Dele [9] noted that students' academic performance is one of the current educational problems of public interest based on current poor level of student's academic performance especially in various higher institutions. Over the years, the achievement of students in building technology has continued to decrease and this has been an issue of concern to major stake holders in vocational and technical education in Nigeria and North-central Nigeria in particular.

Poor academic achievement, according to Aremu \& Sokan [10] is a performance that is adjudged by the examinee/testee as falling below an expected standard. Igberadja [11] acknowledged the worrisome level of poor academic 
achievement of students in vocational technical education subjects in Nigeria. May et al. [12] observed that technical and vocational education are very much still neglected which consequently is robbing the country of the economic development to be contributed by graduates of technical and vocational education. Similarly, Diraso [13] reported that students' prospects for career pursuits in engineering and technical and vocational education were being hampered by their poor performances in core engineering and vocational technical education subjects.

In quest for solution the problem of poor achievement of students in vocational and technical education, Igberadja [11] noted that various factors related to teachers' qualification, age, experience, and gender may affect the academic performance of students in science and technical education. The report of National Board for Technical Education (NBTE) [14] showed that factors that worsen poor achievement of students in vocational and technical education towards an effective career choice are poor background of students, truancy, and language of instruction of the teacher, among others. In addition, Unongo [15] expressed concern over the growing gap between the industrial skill needs and the acquired skill level of students in vocational and technical education. Hence, it is crystal clear that academic achievement of students in building technology is greatly influenced by an interplay of some factors and socioeconomic variables. It is based on this background that this study investigated socioeconomic determinants of students' academic achievement in building technology in Northcentral Nigeria. Specifically, the study identified challenges facing students of building technology in the study area and also socio-economic determinants influencing students' achievement in building technology.

\section{METHOD}

This study was carried out in Northcentral geopolitical zone of Nigeria using survey research design. North-central Nigeria is made up of 6 states which include Kogi, Niger, Benue, Kwara, Plateau, Nassarawa and the Federal Capital Territory. Random sampling technique was used to select three states (Niger, Kogi and Plateau) out the existing six states in the zone. From the three selected states, the four colleges of education that offers vocational and technical education including building technology were sampled. These include Niger State College of Education, Minna; Kogi State College of Education, Ankpa; Kogi State College of Education, Kabba and Federal College of Education, Pankshin, Plateau State. The sample for the study was 113 NCE II students of Building Technology drawn from the four Colleges of Education.

Data for this study were obtained from both primary and secondary sources. Through the use of a structured questionnaire, data on socioeconomic attributes of the students such as age, gender, study hours, parents' education background, family size, stipends received per month and students' health status among others were collected. To avoid deception on academic achievement, data on each of the students' Cumulative Grade Point Average (CGPA) were collected from departmental academic records.

Data collected were analysed using descriptive statistics and Ordinary Least 
Square (OLS) multiple regression analysis. Descriptive statistics such as frequency, percentages, mean and standard deviation were used to identify the challenges facing students of Building technology in Colleges of Education in the study area. The intensity of the challenges facing the students was graded into 4-point rating scale of Very Serious, (VS) $=4$, Serious $(S)=3$, Less Serious $(L S)=2$ and Not Serious $(\mathrm{NS})=1$. The mean ratings of the students based on the 4-point rating scale were interpreted using boundary limit as stated in Table 1.

Table 1. Response Categories

\begin{tabular}{lcc}
\hline Response Categories & $\begin{array}{c}\text { Ordinal } \\
\text { values }\end{array}$ & $\begin{array}{c}\text { Boundary } \\
\text { limits }\end{array}$ \\
\hline Very Serious (VS) & 4 & 3.50 to 4.00 \\
Serious (S) & 3 & 2.50 to 3.49 \\
Less Serious (LS) & 2 & 1.50 to 2.49 \\
Not Serious (NS) & 1 & 1.00 to 1.49 \\
\hline
\end{tabular}

Therefore, items with mean values of 3.50 to 4.00 were interpreted as very serious challenges, those between 2.50 to 3.49 were interpreted as serious challenges, and those between 1.50 to 2.49 and 1.00 to 1.49 were interpreted as less serious and not serious challenges respectively.

Ordinary least squire multiple regression analysis was employed to estimate determinants of academic achievement of NCE II students of Building Technology. Students' CGPA was used as a proxy of their academic achievement. The implicit form of the regression model is stated thus:

$\mathrm{Y}=\mathrm{f}\left(\mathrm{X}_{1}, \mathrm{X}_{2}, \mathrm{X}_{3}, \mathrm{X}_{4}, \mathrm{X}_{5}, \mathrm{X}_{6}, \mathrm{X}_{7}, \mathrm{X}_{8}, \mathrm{X}_{9}, \mathrm{X}_{10}, \mathrm{X}_{11}+\ell\right.$

Where:

$\mathrm{Y}=$ Students' Cumulative Grade Point Average $\mathrm{X}_{1}=$ Gender of the students $($ male $=1 ;$ female $=0)$ $\mathrm{X}_{2}=$ Age of the students (in number of years)
$X_{3}=$ Number of study hours (in number)

$\mathrm{X}_{4}=$ Parents' education background (literate $=1$, illiterate $=0$ )

$\mathrm{X}_{5}=$ Family size (in number of persons)

$\mathrm{X}_{6}=$ Family type $($ nuclear $=1$, polygamous $=0$ )

$\mathrm{X}_{7}=$ Stipend per month (in naira

$\mathrm{X}_{8}=$ Engagement in group reading $(\mathrm{yes}=1$, no $=0)$

$\mathrm{X}_{9}=$ Frequency of parents' visits to school (in number of times)

$\mathrm{X}_{10}=$ Students health status (having health challenge $=1$, no challenge $=0$ )

$\mathrm{X}_{11}=$ Number of credit pass in SSCE/NECO (in number) $\mathrm{X}_{12}=$ Truancy (number of time absent from lecture in last semester).

$\mathrm{X}_{13}=$ Accommodation status in School (campus $=1$, offcampus $=0$ )

$\mathrm{X}_{14}=$ Involvement in Social Activities $(\mathrm{yes}=1$, no $=0$ )

The explicit form of the linear model is as follows:

$\mathrm{Yc}=\mathrm{b}_{0}+\mathrm{b}_{1} \times 1+\mathrm{b}_{2} \times 2+\mathrm{b}_{3} \times 3+\mathrm{b}_{4} \times 4+\mathrm{b}_{5} \times 5+\ldots \ldots+\mathrm{e}$

Three functional forms: linear, semi-log and double-log were estimated using the ordinary least square. This was considered necessary in order to select the functional form with the best fit. In the semi-log and double $\log$ forms, 0 values were not logged because, the number 0 is undefined for log.

\section{RESULTS AND DISCUSSION}

Figure 1 shows that majority of $80.5 \%$ of the NCE II students of Building Technology are males while the remaining $19.5 \%$ of the students are females. This indicates that building technology education in Nigeria is male dominated. The findings of this study agreed with that of Egun \& Tibi [16] who identified wide gender gap of students' enrolment in vocational education in favor of males. Similarly, the findings of this study also conformed to that of Dokubo \& Deebom [17] whose findings showed gender disparity in students enrollment in technical education with very low enrolment of females in technical education in Nigeria. 


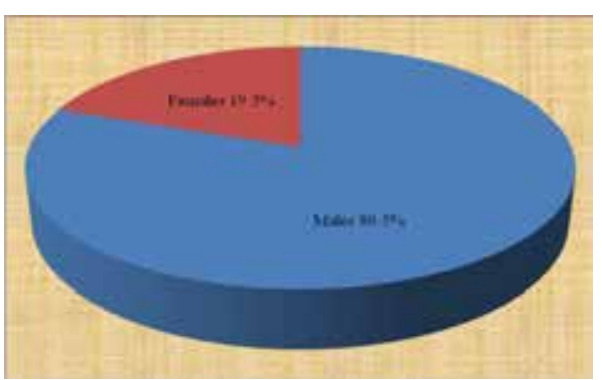

Figure 1. Gender Distribution of the Students

Figure 2 reveals that majority of $43.4 \%$ of the NCE II students of Building Technology are within $15-20$ years age bracket, $31.8 \%$ are within $21-25$ years age bracket, $17.7 \%$ of the students are within $26-$ 30 years age bracket while $7.1 \%$ of the students are 31 years and above. The result shows that most of NCE II students in Northcentral Nigeria are very young with few old students. In affirmation of this result, Ademola et al. [18] found that about sixty-three percent of the population of undergraduate students in Nigeria tertiary institution are under the age of twenty years.

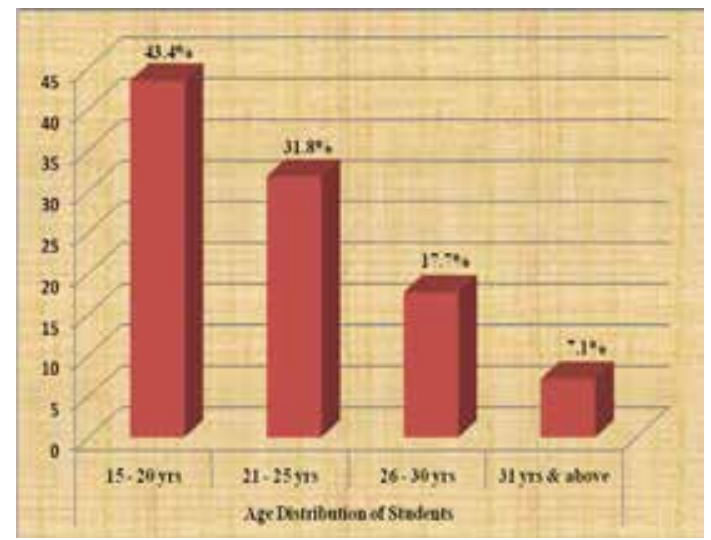

Figure 2. Age Distributions of the Students

Table 1 shows the results of the regression analysis on determinants of students' academic achievement in Building technology in terms of CGPA. Three functional forms (linear, semi-log and double$\log$ ) were statistically estimated, the double$\log$ functional form had the best fit, based on the $\mathrm{R}^{2}$ value of (0.71), number and levels of significance of independent variables and signs. For instance, the $\mathrm{R}^{2}$ value of 0.71 indicates that the significant variables in the model are responsible for about $71 \%$ of the variation in CGPA of the Building Technology students. The F-value of (27.854) implies that the overall equation was significant at $(\mathrm{p}<0.01)$ while Durbin-Watson (DW) of 2.230 indicates absence of autocorrelation. Out of the 14 independent variables specified in the model, nine significantly influence CGPA of NCE II students of Building Technology. The significant variables include: gender, age, study hours, family size, stipends per month (N), group reading, students health status, number of credit pass in SSCE/NECO and truancy.

The coefficient gender was significant at $5 \%$ and positively related with academic achievement of NCE students of Building technology. The result implies that male students have higher CGPA than their female counterparts. Igberadja [11] found that various factors related to qualification, age, experience, and gender may affect the academic performance of students in science and technical education. Age of the students was highly significant at $1 \%$ but negatively related with academic achievement in Building technology. This indicates that the higher the age of the students, the lower their academic achievement. Hence, younger students in the study have higher CGPA than the older ones. An increase in age of 
individual may translate to increase in responsibilities that may negatively interfere with academic programme of students. The findings of this study agreed with that of Ogunsola et al. [19] who found that several factors such as age, gender, geographical belonging, ethnicity, socioeconomic status, language, religious affiliations, family size and type play significant roles in determining the academic achievement of students. The coefficient of study hour was highly significant and positively related with CGPA at $1 \%$. This result indicates that the more the number of study hours of students increase, the more their achievement in terms of higher CGPA. This conformed with a priori expectation. The findings of this study conformed with that of Akinoso [20] who found that students' ability to study at home and student attitude to instruction significantly predicted their academic achievement in Mathematics. Alufohai [21] found that effective instruction and text messaging significantly influence student's academic achievement.

The coefficient of family size was significant at $5 \%$ but negatively related with academic achievement in Building technology. This showed that the higher the number of the people in students family, the lower their CGPA. The implication of the inverse relationship of family size with achievement could have resulted from inadequate finance for necessary instructional materials as a result of large family size the student come from. In this case, students from small sized families have better academic achievement. Stipend (pocket money) received from parent and guidance was highly significant at $1 \%$ and positively related with academic achievement in Building technology students. This suggests that the higher the higher the money made available to students, the more their ability to purchase the necessary instructional materials and faculties for quality learning, hence, the higher their CGPA. Abdullahi et al. [22] in a study equally found that family size and feeding, provision of resource materials, visits to schools, provision of pocket money, and residential type (accommodation) statistically and significantly influence academic achievement of students in schools. Jeynes [23] reported that provision and access to various educational materials and resources influence academic achievement of students. The coefficient of group reading of Building technology students was highly significant at $1 \%$ and positively related with CGPA. This was expected and students in reading groups share ideas and collaborate with one another for increased academic achievement in terms of higher CGPA.

Students' health status was highly significant but negatively related with academic achievement in Building technology at $1 \%$. The negative implication of the relationship between health and academic achievement indicates that students with health challenges are more likely to have low CGPA than those that have no health challenges. This conforms with a priori expectation as health challenges could distract students' attention from learning and understanding which could culminate to poor achievement performance. The findings of this study on influence of health challenge of performance agreed with the result of Chude [24] who found a significant but negative relationship between students with health 
challenges and academic performance. The coefficient of number of credit pass at SSCE/NECO was highly significant at $1 \%$ and positively related with academic achievement in Building technology students. The result shows that students with higher number of credit pass have higher CGPA at the end of their secondary year in Building technology. Of cause, this is expected transition from secondary school to higher institution. The findings corroborated that of Akenbor \& Ibanichuka [25] who found that students' achievement is significantly influenced by class size, entry requirement, access to functional library, semester duration, contact hours, and curriculum contents. Truancy was significant but negatively related with CGPA of Building technology students at $10 \%$. The more the students stay away from class, the lower the academic achievement at the end of the session. The report of West Africa Examination Council [26] ascertained that poor background of students and truancy constitute part of the factors that significantly influence achievement.

Table 2 presents the mean ratings of the students on the challenges they are facing in studying building technology in colleges of education in North-central Nigeria. From the result, epileptic power supply to classroom and students' hostels for private study/reading (3.78), inadequate ICT facilities for effective learning of building technology in the school (3.73), lack of functional building technology workshop in the school (3.60), unequipped libraries in the school for relevant book consultation by students (3.56), lack or inadequate instructional materials (3.54) and poor classroom conditions in the school (3.52) had mean values that are within the boundary limit of $3.50-4.00$ on 4-point rating scale. This indicates that the identified items are very serious challenges facing building technology students. Poor attitudes of most students to learning of Building technology (3.44), too many number of courses in building technology offered by students (3.40), inadequate spacing between courses/paper during examination (3.33), inadequate exposure of students to practical works in building technology (3.16), the use of ineffective teaching methods by most lecturers for instructional delivery (2.88) and short lecture periods on time table for building technology instruction (2.75) had mean values that are within the boundary limit of $2.50-$ 3.49 on 4-point rating scale. This indicates that the identified items are serious challenges facing building technology students in Northcentral Nigeria.

The findings of this study agreed with Aremu \& Sokan [10] who found out that the students' factors of poor academic performance were poor study habits, psychological adjustment problems, lack of interest in school programme, low retention, association with wrong peers, low achievement motivation and emotional problems. Ogundele et al. [27] expressed worries about the not-too-encouraging attitude of students which has been an impediment to their good academic performance in the country. In addition, Ong et al. [28] who found that students' lack of financial support, absenteeism, truancy, use of local language in the classroom, lack of interest and joy in teachers' lessons and learning disability cause poor academic performance of students. Ogundele et al. [27] also found that polygamous and large families contributed to 
poor academic performance of the students. This is because, parents' inability to provide breakfast, textbooks and basic school needs for their children, less interaction with children's teachers and less involvement in the Parents-Teachers Association (PTA) resulted in poor academic performance of students.

Poor attitudes of some lecturers of building technology to work (2.45), very short semester duration (2.39) and inadequate linkages between colleges of education and building industry (2.34) had mean values that are within the boundary limit of $1.50-2.49$ on 4-point rating scale. This implies that the identified items are not serious challenges facing building technology students in Northcentral Nigeria.

Table 1. Parameter Estimates of the Multiple Regression of the Socio-economic Determinants of Building Technology Students' Achievement.

\begin{tabular}{|c|c|c|c|}
\hline Variables & Linear & Semi-Log & Double-Log $\{\mathrm{a}\}$ \\
\hline \multirow[t]{2}{*}{ INTERCEPT } & 8.605 & 10.943 & 8.877 \\
\hline & $(4.211)^{* *}$ & $(0.612)^{* * *}$ & $(1.517)^{* * *}$ \\
\hline \multirow[t]{2}{*}{ Gender } & 1.862 & 0.298 & 0.699 \\
\hline & $(0.458)^{* * *}$ & $(0.303)$ & $(0.303)^{* *}$ \\
\hline \multirow[t]{2}{*}{ Age } & -21.308 & -0.040 & -1.244 \\
\hline & $(20.781)$ & $(0.010)^{* * *}$ & $(0.282)^{* * *}$ \\
\hline \multirow[t]{2}{*}{ Study Hours } & 1.264 & 9.006 & 1.062 \\
\hline & $(4.697)^{* * *}$ & $(6.570)^{* * *}$ & $(6.997)^{* * *}$ \\
\hline \multirow[t]{2}{*}{ Parents' Education Background } & 1.747 & 0.102 & 0.001 \\
\hline & $(0.483)$ & $(0.083)$ & $(0.377)$ \\
\hline \multirow[t]{2}{*}{ Family Size } & -3.795 & -0.011 & -0.452 \\
\hline & $(4.465)$ & $(0.028)$ & $(0.193)^{* *}$ \\
\hline \multirow[t]{2}{*}{ Family Type } & -3.321 & 0.209 & 0.005 \\
\hline & $(-0.893)$ & $(0.376)$ & $(1.374)$ \\
\hline \multirow[t]{2}{*}{ Stipend per month (N) } & 1.434 & 0.068 & 0.338 \\
\hline & $(0.457)^{* * *}$ & $(0.014)^{* * *}$ & $(0.032)^{* * *}$ \\
\hline \multirow[t]{2}{*}{ Group Reading } & 0.283 & 0.118 & 0.027 \\
\hline & $(0.186)$ & $(0.038)^{* * *}$ & $(0.009)^{* * *}$ \\
\hline \multirow[t]{2}{*}{ Frequency of Parents' Visits } & 0.117 & 0.100 & 0.068 \\
\hline & $(0.120)$ & $(0.060)^{*}$ & $(0.058)$ \\
\hline \multirow[t]{2}{*}{ Students Health Status } & -2.025 & -0.125 & -0.218 \\
\hline & $(1.244)$ & $(0.055)^{* *}$ & $(0.060)^{* * *}$ \\
\hline \multirow[t]{2}{*}{ No Credit Pass in SSCE/NECO } & 3.241 & 3.387 & 0.203 \\
\hline & $(1.393)^{* *}$ & $(0.928)^{* * *}$ & $(0.065)^{* * *}$ \\
\hline \multirow[t]{2}{*}{ Truancy } & -1.381 & 0.320 & -0.046 \\
\hline & $(0.989)$ & $(0.285)$ & $(0.024)^{*}$ \\
\hline \multirow[t]{2}{*}{ Accommodation Status } & -0.609 & -0.455 & -0.263 \\
\hline & $(0.251)^{* *}$ & $(0.205)^{* *}$ & $(0.189)$ \\
\hline \multirow[t]{2}{*}{ Involvement in Social Activities } & -1.306 & -0.215 & -0.090 \\
\hline & $(1.021)$ & $(0.159)$ & $(0.063)$ \\
\hline No of Observation & 113 & 113 & 113 \\
\hline $\mathrm{R}^{2}$ & 0.582 & 0.685 & 0.709 \\
\hline Durbin-Watson & 1.865 & 2.001 & 2.130 \\
\hline F-value & 9.152 & 21.374 & 27.888 \\
\hline
\end{tabular}

Note: $* * *$ denotes sig. at $1 \% ; * *$ denotes sig. at $5 \% ; *$ denotes sig. at $10 \%$.

Figures in parentheses () are standard errors; $\{\mathbf{a}\}=$ lead equation; 
Table 2. Mean Ratings of the Challenges Facing Building Technology Students $(n=113)$

\begin{tabular}{|c|c|c|c|c|}
\hline \multirow{2}{*}{ SN } & \multirow{2}{*}{ Challenges } & \multirow[b]{2}{*}{$\bar{X}$} & \multicolumn{2}{|r|}{ Ranking } \\
\hline & & & SD & Order \\
\hline 1 & $\begin{array}{l}\text { Epileptic power supply to classroom and students' hostels for private } \\
\text { study/reading }\end{array}$ & $3.78 * * *$ & 0.44 & $1 \mathrm{st}$ \\
\hline 2 & $\begin{array}{l}\text { Inadequate ICT facilities for effective learning of building technology in } \\
\text { the school }\end{array}$ & $3.73 * * *$ & 0.48 & 2nd \\
\hline 3 & Lack of functional building technology workshop in the school. & $3.60 * * *$ & 0.47 & $3 \mathrm{rd}$ \\
\hline 4 & $\begin{array}{l}\text { Unequipped libraries in the school for relevant book consultation by } \\
\text { students }\end{array}$ & $3.56^{* * *}$ & 0.52 & 4 th \\
\hline 5 & Lack or inadequate instructional materials & $3.54 * * *$ & 0.45 & 5 th \\
\hline 6 & Poor classroom conditions in the school & $3.52 * * *$ & 0.49 & 6 th \\
\hline 7 & Poor attitudes of most students to learning of building technology & $3.44 * *$ & 0.48 & 7 th \\
\hline 8 & Too many number of courses offered by students & $3.40^{* *}$ & 0.55 & 8 th \\
\hline 9 & Inadequate spacing between courses/paper during examination & $3.33^{* *}$ & 0.48 & 9th \\
\hline 10 & Inadequate exposure of students to practical works in building technology & $3.16^{* *}$ & 0.51 & 10th \\
\hline 11 & $\begin{array}{l}\text { The use of ineffective teaching methods by most lecturers for instructional } \\
\text { delivery }\end{array}$ & $2.88^{* *}$ & 0.50 & 11 th \\
\hline 12 & Short lecture periods on time table for building technology instruction & $2.75^{* *}$ & 0.64 & 12 th \\
\hline 13 & Poor attitudes of some lecturers of building technology to work & $2.45 *$ & 0.47 & 13 th \\
\hline 14 & Very short semester duration & $2.39 *$ & 0.52 & 14 th \\
\hline 15 & Inadequate linkages between colleges of education and building industry & $2.34 *$ & 0.50 & 15 th \\
\hline
\end{tabular}

Note: *** Very Serious Challenges; ** Serious Challenges; * Not Serious Challenges

\section{CONCLUSION}

The enhancement of academic achievement and interest of students in workbased learning such as a vocational and technical education has continued to engage the attention of major stakeholders in Nigerian education and economic sectors. It is imperative to state that lots of factors play roles in achievement of students in school. This study therefore investigated socioeconomic determinants of students' academic achievement in building technology using colleges of education in North-central Nigeria as case study. Based on the data collected and analysed, the study found that building technology education in Nigeria is male dominated. The significant variables that influenced students' achievement in building technology were: gender, age, study hours, family size, stipends per month ( $)$, group reading, students' health status, number of credit pass in SSCE/NECO and truancy. The challenges facing Building technology students in the study area include epileptic power supply to classroom and students' hostels for private study/reading, inadequate ICT facilities for effective learning of Building technology in the school, lack of functional building technology workshop in the school, unequipped libraries in the school for relevant book consultation by students, lack or inadequate instructional materials and poor classroom conditions in the school among others.

\section{REFERENCES}

[1] R. Okoye and A. M.O., "Technical and Vocational Education in Nigeria: Issues, Challenges and a Way Forward," J. Educ. Pract., vol. 7, no. 3, pp. 113-118, 2016.

[2] T. M. Kehinde and L. A. Adewuyi, "Vocational and Technical Education: A Viable Tool for Transformation of the Nigerian Economy," Int. J. Vocat. Tech. Educ. Res., vol. 1, no. 2, pp. 22- 
$31,2015$.

[3] B. Manyindo, "Pilot Project on CoOperation between Educational Institution and Enterprise in Technical Vocation Education in Ganda," in UNESCO Seminar, 2005.

[4] Nigerian Educational Research and Development Council (NERDC), National Policy on Education. Federal Republic of Nigeria, 2014.

[5] J. E. Maurice, P. B. Asu-nandi, and E. A. Ntui, "Entrepreneurial skills Development and the Building Technology Curriculum," Niger Delta J. Educ., vol. 3, no. 1, pp. 600-607, 2017.

[6] C. E. Okoro, "Innovations in Building Technology and Curriculum Revision Needs for Building Construction Programmes of Colleges of Education (Technical)," University of Nigeria, Nsukka, 2010.

[7] S. H. O. Egboh, "Strategies for Improving the Teaching of Science, Technical and Vocational Education in Schools and Colleges in Nigeria," in one day Intensive Nationwide Training/Workshop Organized by the Centre for Science, Technical and Vocational Education Research Development, 2009.

[8] UNESCO, Technical and Vocational Educational Training. Paris: United Nations Educational Scientific and Cultural Organization (UNESCO), 2001.

[9] C. O. O. Kolawole and A. Dele, "An Examination of the National Policy of Language Education in Nigeria and its Implications for the Teaching and Learning of the English Language," Ibadan J. Educ. Stud., vol. 2, no. 1, pp. 12-20, 2002.

[10] A. Aremu and B. Sokan, "A MultiCausal Evaluation of Academic Performance of Nigerian Learners:
Issues and Implications for National Development," University of Ibadan, 20032.

[11] S. Igberadja, "Effects of Teachers' Gender and Qualification on Students' Performance in Vocational Technical Education," J. Tech. Educ. Train., vol. 8, no. 1, pp. 34-42, 2016.

[12] A. May, I. A. Ajayi, B. B. Arogundadade, and H. T. Ekundayo, "Assessing Realities And Challenges of Technical Education in Imo State Secondary School Education System in Nigeria," J. Educ. Adm. Plan., vol. 7, no. 3, 2007.

[13] D. Diraso, S. S. Manabete, K. Amalo, Y. Mbudai, A. Arabi, and A. Jaoji, 'Evaluation of Students' Performance in Technical and Engineering Drawing Towards an Effective Career Choice in Engineering, Technical and Vocational Education," Int. J. Educ. Res. Dev., vol. 2, no. 4, pp. 89-97, 2013.

[14] Vocational and Technical Education in Nigeria, "National Board for Technical Education (NBTE)," Kaduna, 2012.

[15] J. Unongo, "Comparative Effects of Dialogic Teaching and Coaching Instructional Strategies on Students' Performance, Interest and Retention in Motor Vehicle Mechanic Works in Technical Colleges in Benue State," University of Nigeria, 2015.

[16] A. C. Egun and E. U. Tibi, "The Gender Gap in Vocational Education: Increasing Girls Access in the 21st Century in the Midwestern States of Nigeria," Int. J. Vocat. Tech. Educ., vol. 2, no. 2, pp. 18-21, 2010.

[17] I. N. Dokubo and M. T. Deebom, "Gender Disparity towards Students Enrollment in Technical Education in Rivers State: Causes, Effects and Strategies," Int. J. Res. Granthaalayah, vol. 5, no. 3, pp. 5564, 2014. 
[18] E. O. Ademola, A. T. Ogundipe, and W. T. Babatunde, "Students' Enrolment into Tertiary Institutions in Nigeria: the Influence of the Founder's Reputation - a Case Study," Comput. Inf. Syst. Dev. Informatics Allied Res. J., vol. 5, no. 3, pp. 55-64, 2014.

[19] O. Ogunsola, K. Osuolale, and A. Ojo, "Parental and Related Factors Affecting Students' Academic Achievement in Oyo State, Nigeria," $J$. Soc. Behav. Educ. Econ. Bus. Ind. Eng., vol. 8, no. 9, pp. 3129 - 3, 2014.

[20] S. O. Akinoso, "Correlates of Some Factors Affecting Students Achievement in Secondary School Mathematics in Osun State, Nigeria," University of Ibadan, 2017.

[21] P. J. Alufohai, "School-Based Factors Affecting Senior Secondary School Students' Achievement in English Language in Edo State," Eur. J. Res. Reflect. Educ. Sci., vol. 4, no. 9, pp. 36-43, 2016.

[22] H. A, Abdullahi., M. R. S, Mlozi and G. K. Nzalayaimisi, "Determinants of Students' Academic Achievement in Agricultural Sciences: A Case Study of Secondary Schools in Katsina State, Nigeria," African Educ. Res. J., vol. 3, no. 1, pp. 80-88, 2015.

[23] W. H. Jeynes, "Examining the Effect of Parental Absence on the Academic Achievement of Adolescents: The challenge for controlling family Income," J. Fam. Econ. Issues, vol. 23, no. 2, pp. $189-210,2002$.
[24] E. C. Chude, "Students' Factors Influencing their Academic Achievement in Technical Colleges in South-east, Nigeria," University of Nigeria, 2017.

[25] C. O. Akenbor and E. A. . Ibanichuka, "Institutional Factors Influencing the Academic Performance of Students in Principles of Accounting," Int. J. High. Educ. Manag., vol. 1, no. 1, pp. 15-26, 2014.

[26] West Africa Examination Council [WAEC, "Statistics of Entry Performance in WAEC Examinations Highlights of Results released," Abuja, Nigeria, 2014.

[27] G. A. Ogundele, S. . Olanipekun, and J. K. Aina, "Causes of Poor Performance in West African School Certificate Examination (WASCE) in Nigeria," Sch. J. Arts, Humanit. Soc. Sci., vol. 2, no. 5B, pp. $670-676$, 2014.

[28] L. C. Ong, V. Chandron, Y. . Lim, B. Chem, and K. Poh, "Factors Associated with Poor Academic Achievement among Urban Primary School Children in Malaysia," Singapore Med. J., vol. 51, no. 3, pp. 247-252, 2010. 